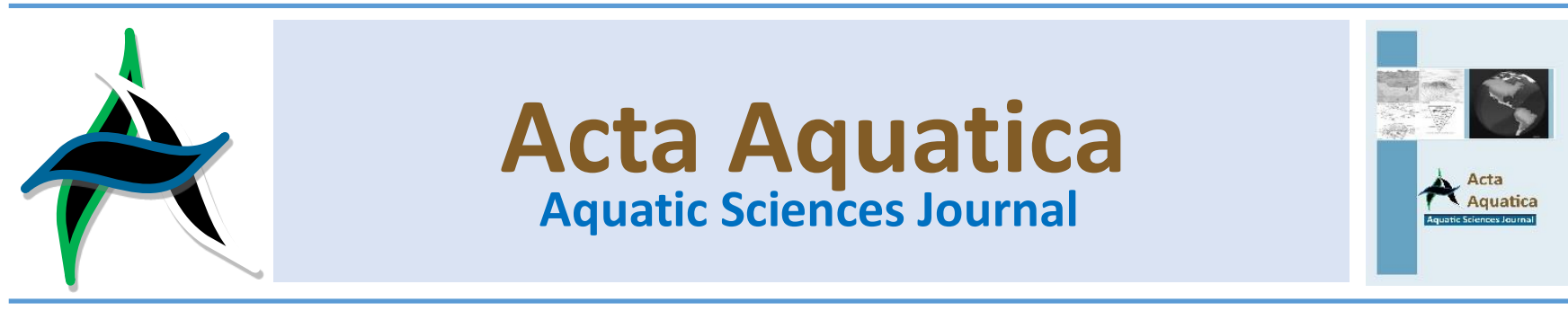

\title{
Spread of the arrow bulleye Priacanthus sagittarius Starnes, 1988 in the Mediterranean Sea
}

\author{
Mehmet Gökoğlu ${ }^{a, *}$ and Serkan Teker ${ }^{a}$
}

${ }^{a}$ Faculty of Fisheries, Akdeniz University

\begin{abstract}
Habitat of the family Priacanthidae is tropical and subtropical Atlantic, Indian, and Pacific oceans. The features of the family members are generally very big eyes, deep bodies, upturned mouth, and generally reddish color. In the this paper, we report the presence of an arrow bulleye Priancanthus sagittarius in coast of Turkey waters in the Mediterranean Sea. On the $27^{\text {th }}$ December, 2017, a single specimen of $P$. sagittarius was collected by Mr. Hüseyin Çınar, captain of the commercial bottom trawler Furkan Reis vessel, off the Taşucu, Mersin $\left(36^{\circ} 07^{\prime} 2.82^{\prime \prime} \mathrm{N} 33^{\circ} 51^{\prime} 6.42^{\prime \prime} \mathrm{E}\right)$ Turkey coasts. The specimen of $P$. sagittarius was collected at a depth of approximatetly $100 \mathrm{~m}$ by a bottom trawl net; the mesh size of $22 \mathrm{~mm}$. The collected specimen of arrow bulleye $P$. sagittarius was $255 \mathrm{~mm}$ in total length (TL) and $307 \mathrm{~g}$ in total weight (TW). The finding of the present study is the first record of specimen along shores of the Mediterranean of Turkey. This record suggests that this species is spread towards to west along in the Mediterranean.
\end{abstract}

Keywords: Priacanthus sagittarius; spread; Coast of Turkey; Mediterranean

\section{Introduction}

Habitat of the family Priacanthidae is tropical and subtropical Atlantic, Indian, and Pacific oceans. The features of the family's family members are generally very big eyes, deep bodies, upturned mouth, and generally reddish color (Sterness, 1988). The family Priacanthidae contains four genera (two genera is synonim) such as the genus Priacanthus and 19 species. Priancanthus sagittarius (Starnes, 1988) belong to the genera Priacanthus (Eschmeyer, 2014; Farrag et al., 2016). First record of arrow bulleye $P$. sagittarius in the Mediterranean was reported by Goren et al. (2010). After this time, $P$. sagittarius was reported in the Mediterranean by Golani et al. (2011) and Farrag et al. (2016). In addition, Elongate bulleye Priacanthus prolixus Starnes, 1988 belonging to the genera Priacanthus was reported from the coasts of iskenderun Bay of the Mediterranean by Gürlek et al. (2017). In the this paper, we report the presence of an arrow bulleye $P$. sagittarius in the coasts of the Mediterranean Sea of Turkey.

* Corresponding author: Faculty of Fisheries, Akdeniz University, 07058. Antalya/Turkey. Tel: +905358554167

e-mail:gokoglu@akdeniz.edu.tr

doi: http://doi.org/10.29103/aa.v5i1.455

\section{Materials and methods}

On the $27^{\text {th }}$ December, 2017, a single specimen of $P$. sagittarius was collected by Mr. Hüseyin Çınar, captain of the commercial bottom trawler Furkan Reis vessel, off the Taşucu, Mersin (36 $\left.07^{\prime} 2.82^{\prime \prime} \mathrm{N} 33^{\circ} 51^{\prime} 6.42^{\prime \prime} \mathrm{E}\right)$ Turkey coasts (Figure 1 ).

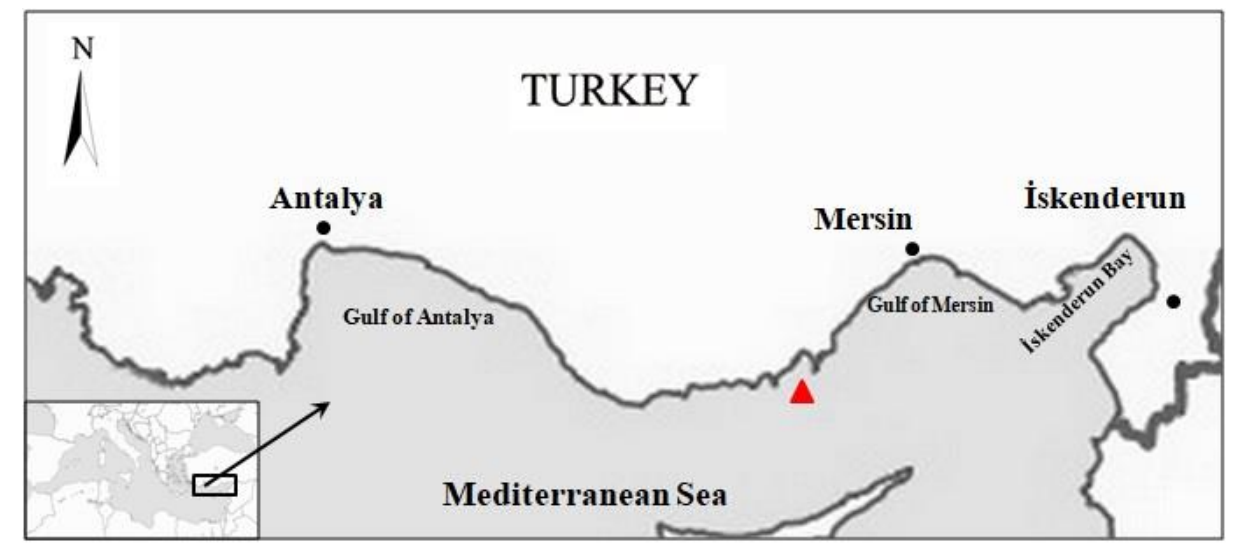

Figure 1. Sampling location.

The specimen of $P$. sagittarius was collected at a depth of approximatetly $100 \mathrm{~m}$ by a bottom trawl net; the mesh size of $22 \mathrm{~mm}$. The specimen was identified according to Starnes (1988); Golani et al. (2011); Farrag et al. (2016). In all counts, measurements and in morphological characterization Hubbs and Lagler (1947) were followed. The specimen stored in 4\% formol solution and was deposited in the Museum of the Faculty of Fisheries, Akdeniz University (AU-SUF/2017-4). 


\section{Result and discussion}

The collected specimen of arrow bulleye $P$. sagittarius was $255 \mathrm{~mm}$ total length (TL) and $307 \mathrm{~g}$ weight (TW) (Figure 2). Body elongate; caudal fin slight rounded; Soft rays of dorsal and anal fins relatively long; Pectoral fins were relatively short and broadly pointed, shorter than pelvic spines.

\section{Conclusion}

With the opening of the Suez Canal in 1869, many alien species and numbers have increased in the Mediterranean (Zenetos et al., 2012; Katsanevakis et al., 2014). P. sagittarius has widely Indo-west Pacific distribution from the Red Sea to Japan, Australia to Samoa (Starnes, 1988). Previous studies than this report, it was recorded from the Coast of Tel-Aviv by Goren et al. (2010), from The Haifa Bay, Israel by Golani et al. (2011) and from Egyptian waters by Farrag et al. (2016). The finding of the present study is the first record of specimen along shores of the Mediterranean of Turkey. This record suggests that this species is spread towards to west along in the Mediterranean.

Some species originated from Red Sea are not economically and consumable. Some species are even in the group of dangerous sea organisms. However, some are evaluated economically. From this point of view, the last species we recorded is a species that can be consumed, harmless and economical.

Figure 2. Priancanthus sagittarius.

$P$. sagittarius samples other meristic counts and body proportions: Dorsal fin rays $\mathrm{X}+13$; anal fin rays III +13 ; pectoral fin rays 19 , and pelvic fin rays $I+5$. Head length is $76,17 \mathrm{~mm}$; body depth is $81 \mathrm{~mm}$; eye diameter is $35,17 \mathrm{~mm}$.

Color: Body red, becoming slightly pinkish in lateral part. a black spot on the upper half of the membrane between the first and second dorsal spines; the upper margin of the first dorsal magrin and psterior of body is dark red. Posterior end of soft dorsal ray portion and caudal fin with light grey zone and dark margin. between 1-3 pelvic rays orange-brown with black point at base.

One undifined specimens was caught by a commercial trawler from Taşucu, Mersin Bay. Specimen was identified $P$. sagittarius according to Starness, (1988). These samples can be distinguished from other species belong genus Priacanthus in the Red Sea by having black marks on the pelvic fin base, a dark spot on the upper margin of the membrane between 1-2 dorsal spines, in addition to the long 10th dorsal spine (more than twice the length of the 2 nd dorsal spine) and rounded caudal fin according to Goren et al. (2010); Golani et al. (2011).

The sample was collected by commercial trawl operation at a depths of about $100 \mathrm{~m}$ and on the rocky bottom. Its depth range is between "60 to $100 \mathrm{~m}$ ", taccording to Starnes (1988). Its habitat is "in sheltered reefs in moderate depths, usually in caves or under coral plates (Kuiter and Tonozuka, 2001); may also be found in rocky and open areas (Allen and Erdmann, (2012); Froese and Valdestamon, 2018). While Goren et al. (2011) reported the distribution of this specimen ranged between surface and $440 \mathrm{~m}$, Golani et al. (2011) also agreed same depth range.

P. sagittarius grows to maximum $279 \mathrm{~mm}$ (Starnes, 1998) and feeds mainly on zooplanktoon, cephalopods, crusteceas and small fishes (Allen and Erdmann, 2012).

\section{Bibliografi}

Allen, G.R., M.V. Erdmann, 2012. Reef fishes of the East Indies. Perth, Australia: Universitiy of Hawai'i Press, Volumes IIII. Tropical Reef Research.

Eschmeyer, W.N., Catalog of fishes. Updated internet version of 4 January 2014., 2014. Available at: http://research.calacademy.org/research/ichthyology/ catalog/fishcatmain.asp (accessed 21 June 2015).

Farrag, M. M., Jawad, L. A., Elhaweet, A. E. A., 2016. Occurrence of the arrow Bulleye Priacanthus sagittarius (Teleostei: Priacanthidae) in the Egyptian coast of the Mediterranean Sea. Marine Biodiversity Records, 9(1), 6.

Froese R, Valdestamon, Roxanne-Rei, 2018. FishBase. World Wide Web electronic publication. http://www.fishbase.org, version (01/2018)

Golani, D., Sonin, O., Edelist, D., 2011. Second records of the Lessepsian fish migrants Priacanthus sagittarius and Platax teira and distribution extension of Tylerius spinosissimus in the Mediterranean. Aquatic Invasions, 6 (Suppl 1), S7-S11.

Goren, M., Stern, N., Galil, B. S., Diamant, A., 2010. First record of the Indo-Pacific arrow bulleye Priacanthus sagittarius Starnes, 1988 in the Mediterranean Sea. Aquatic Invasions, 5 (Suppl 1), S45-S47.

Gürlek, M., Ergüden, D., Turan, C., 2017. First Record of Elongate Bulleye Priacanthus prolixus in the Mediterranean Sea. 
Hubb, C. L., Lagler. K. F., 1947. Fishes of the Great Lakes region. Bulletin Cranbrook Institute of Science. 26: 1-186.

Katsanevakis, S., Coll, M., Piroddi, C., Steenbeek, J., Ben Rais Lasram, F., Zenetos A., Cardoso, A.C., 2014. Invading the Mediterranean Sea: biodiversity patterns shaped by human activities. Frontiers in Marine Science. 2014, 1:32.

Kuiter, R.H., T. Tonozuka, 2001. Pictorial guide to Indonesian reef fishes. Part 1. Eels- Snappers, Muraenidae - Lutjanidae. Zoonetics, Australia. 1-302.

Starnes, W.C., 1988. Revision, phylogeny and biogeographic comments on the circumtropical marine percoid fish family Priacanthidae. Bulletin of Marine Science. 43:117203.

Zenetos, A., Gofas, S., Morri, C., Rosso, A., Violanti, D., García Raso, J.E., Çinar, M.E., Almogi Labin, A., Ates, A.S., Azzuro, E., Ballesteros, E., Bianchi, C.N., Bilecenoglu, M., Gambi, M.C., Giangrande, A., Gravili, C., Hyams-Kaphzan, O., Karachle, V., Katsanevakis, S., Lipej, L., Mastrototaro, F., Mineur, F., Pancucci Papadopoulou, M.A., Ramos Esplá, A., Salas, C., San Martín, G., Sfriso, A., Streftaris, N., Verlaque, M., 2012. Alien species in the Mediterranean Sea by 2012. A contribution to the application of European Union's Marine Strategy Framework Directive (MSFD). Part 2. Introduction trends and pathways. Mediterranean Marine Science. 2012; 13:328-52. http://dx.doi.org/10.12681/mms.327. 